九州大学学術情報リポジトリ

Kyushu University Institutional Repository

\title{
Impact of Flow Cytometry Crossmatch B-Cell Positivity on Living Renal Transplantation
}

\section{栗原，啓}

ht tp://hdl. hand le. net/2324/1398541

出版情報：九州大学，2013，博士（医学），課程博士 バージョン:

権利関係：やむを得ない事由により本文ファイル非公開（2） 
氏名：栗原 啓

論文題名：

Impact of Flow Cytometry Crossmatch B-Cell Positivity on Living Renal Transplantation

（生体腎移植におけるフローサイトメトリークロスマッチ $\mathrm{B}$ 細胞陽性症例の意義）

区 分：甲

\section{論 文内容の要旨}

背景：フローサイトメトリークロスマッチ（FCXM） T c el1 陽性症例の腎移植成績に関 してはこれまで様々な報告がなされている。これらの報告ではFCXMT 陽性症例は移植予 後が不良であることが示されてきた。近年は、免疫学的なリスクの高い移植において Rituximab・血漿交換・グロブリン療法により良好な成績が得られるとの報告もみられる。 一方でB cel1 陽性症例に関して一定の見解はないのが現状である。今回、生体腎移植に おける B cel1 陽性の意義を明らかにするために、FCXM B ce11 陽性群と陰性群における 拒絶反応および生着率を比較検討した。

対象・方法：2007 年 4 月から 2012 年 6 月までに実施した生体腎移植のうち解析可能で あった 146 例を対象とし、B ce11 陽性（BCXM (+) n=31）群と B ce11 陰性（BCXM（-） $\mathrm{n}=115 ）$ 群の 2 群に分けた。 2 群間での生存率、生着率、拒絶反応を 3 期（0〜3 ケ月、3 ケ月〜 1 年、 1 年〜 2 年) に分けて比較した。拒絶反応に関係する危険因子を特定するた めにステップワイズ法を用いた重回帰分析を行った。

結果：移植後 1 年までの生存、生着率は両群共に $100 \%$ あった。 2 年以内の拒絶発症率 はBCXM (-)で $16.8 \%$ であた。一方、BCXM (+)では $33.2 \%$ あったが、拒絶発症率は 両群間に有意差は認めなかった（ $\mathrm{P}=.201$ 移植後 2 年まで）。感染症発症率にも差は認め なかった。感作歴のみが危険因子となった。結論：BCXM (+) 群は拒絶が多い傾向があった が、生存、生着率に影響はなかった。また本検討では拒絶反応に対する既存抗体の関与 が示唆されたものの統計学的有意差は認められなかった。今後、FCXM B cel1 陽性の臨 床的意義をより明確にするため長期間の観察が必要である。 